垬

JOURNAL OF ETHNOBIOLOGY

AND ETHNOMEDICINE

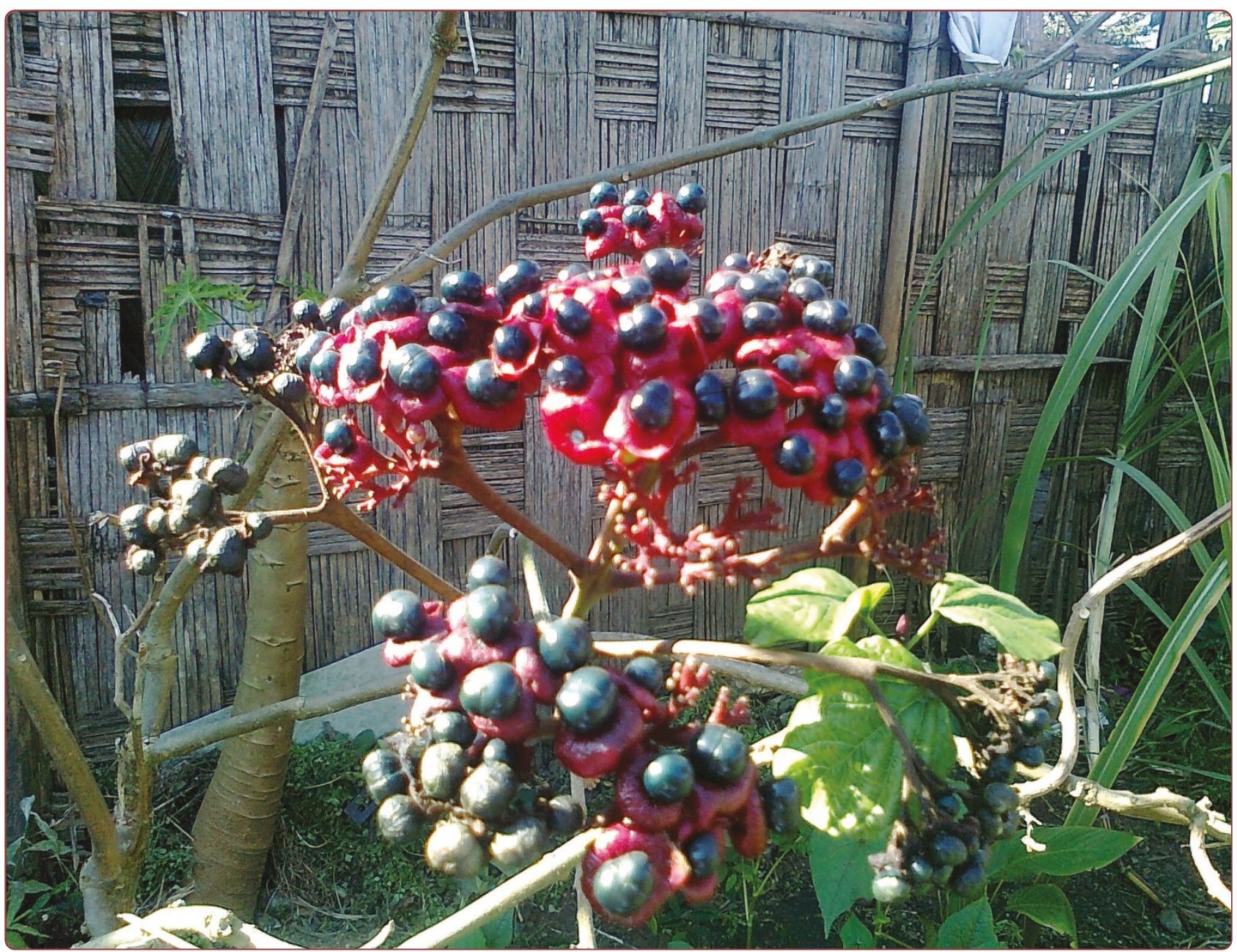

\title{
Ethnobotany of the Monpa ethnic group at Arunachal Pradesh, India
}

Namsa et al. 


\title{
Ethnobotany of the Monpa ethnic group at Arunachal Pradesh, India
}

\author{
Nima D Namsa ${ }^{1,2^{*}}$, Manabendra Mandal ${ }^{1}$, Sumpam Tangjang ${ }^{3}$ and Subhash C Mandal ${ }^{4}$
}

\begin{abstract}
Background: The present paper documents the uses of plants in traditional herbal medicine for human and veterinary ailments, and those used for dietary supplements, religious purpose, local beverage, and plants used to poison fish and wild animals. Traditional botanical medicine is the primary mode of healthcare for most of the rural population in Arunachal Pradesh.
\end{abstract}

Materials and methods: Field research was conducted between April 2006 and March 2009 with randomly selected 124 key informants using semi-structured questionnaire. The data obtained was analyzed through informant consensus factor ( $\left.F_{I C}\right)$ to determine the homogeneity of informant's knowledge on medicinal plants.

Results: We documented 50 plants species belonging to 29 families used for treating 22 human and 4 veterinary ailments. Of the medicinal plants reported, the most common growth form was herbs (40\%) followed by shrubs, trees, and climbers. Leaves were most frequently used plant parts. The consensus analysis revealed that the dermatological ailments have the highest $F_{I C}(0.56)$ and the gastro-intestinal diseases have $F_{I C}(0.43)$. $F_{I C}$ values indicated that there was high agreement in the use of plants in dermatological and gastro-intestinal ailments category among the users. Gymnocladus assamicus is a critically rare and endangered species used as disinfectant for cleaning wounds and parasites like leeches and lice on livestocks. Two plant species (Illicium griffithii and Rubia cordifolia) are commonly used for traditional dyeing of clothes and food items. Some of the edible plants recorded in this study were known for their treatment against high blood pressure (Clerodendron colebrookianum), diabetes mellitus (Momordica charantia), and intestinal parasitic worms like round and tape worms (Lindera neesiana, Solanum etiopicum, and Solanum indicum). The Monpas of Arunachal Pradesh have traditionally been using Daphne papyracea for preparing hand-made paper for painting and writing religious scripts in Buddhist monasteries. Three plant species (Derris scandens, Aesculus assamica, and Polygonum hydropiper) were frequently used to poison fish during the month of June-July every year and the underground tuber of Aconitum ferrox is widely used in arrow poisoning to kill ferocious animals like bear, wild pigs, gaur and deer. The most frequently cited plant species; Buddleja asiatica and Hedyotis scandens were used as common growth supplements during the preparation of fermentation starter cultures.

Conclusion: The traditional pharmacopoeia of the Monpa ethnic group incorporates a myriad of diverse botanical flora. Traditional knowledge of the remedies is passed down through oral traditions without any written document. This traditional knowledge is however, currently threatened mainly due to acculturation and deforestation due to continuing traditional shifting cultivation. This study reveals that the rural populations in Arunachal Pradesh have a rich knowledge of forest-based natural resources and consumption of wild edible plants is still an integral part of their socio-cultural life. Findings of this documentation study can be used as an ethnopharmacological basis for selecting plants for future phytochemical and pharmaceutical studies.

Keywords: Kalaktang Monpa, Ethnobotany, Medicinal plants, Arunachal Pradesh

\footnotetext{
* Correspondence: ndnamsa@yahoo.co.in

'Department of Molecular Biology and Biotechnology, Tezpur University,

Assam 784 028, India

Full list of author information is available at the end of the article
}

\section{() Biomed Central}

(C) 2011 Namsa et al; licensee BioMed Central Ltd. This is an Open Access article distributed under the terms of the Creative Commons Attribution License (http://creativecommons.org/licenses/by/2.0), which permits unrestricted use, distribution, and reproduction in any medium, provided the original work is properly cited. 


\section{Background}

Medicinal plants have been used as sources of medicine in many indigenous communities throughout the world. According to WHO, herbal medicines serve the health needs of about $80 \%$ of the world's population, especially for millions of people in the rural areas of developing countries [1]. India has a rich source of medicinal plants distributed in different geographical conditions and the large sections of Indian population still rely on traditional plant medicines as they are abundantly available, economical, and have little or no side-effects in addition to their cultural acceptability [2-4]. The plant-based knowledge, largely oral, has been transferred from one generation to the next through traditional healers, knowledgeable elders or ordinary people without any written documents. We found that the indigenous knowledge on plant resources was confined to elder members of the study area and the younger's have little or no contribution in this aspect. The study of ethno-botanical plants provides an opportunity for multi-disciplinary and interdisciplinary research work between botany, pharmacology and toxicology, chemistry, anthropology and sociology. The total population of the Arunachal spreading over 16 districts is about 1,019,177 (Population census, 2001), is home to about 28 major tribes and 110 sub-tribes [5]. Each district has its own composition of tribes with distinctive dialects, custom, traditional beliefs and cultural diversity. Medicinal plants have been used as sources of traditional medicine in virtually all tribal cultures and today, according to World Health Organization as many as $80 \%$ of the world's population depend on traditional medicine for their primary healthcare needs. In Arunachal, about 5000 species of angiosperms has been recorded and over 500 species of plants are used in the traditional healthcare system to treat various ailments [6]. Herbal plants use for the preparation of Ayurvedic, Unani, Sidha and homoeopathic medicines are available in different climatic zones of the state [7]. In addition to tribal medicines, plants and their parts are commonly used as food supplements, dying clothes, veterinary health care, handicrafts, rituals, local beverage (beer) production, seasonal fishing, and hunting [8-11]. The existence and dependency on a large number of traditional practices can be thought of as an alternative type of medicine, where the cost and side effects are negligible. Doley et al [12] reported a unique medicinal plant uses among the Nyishi community of Arunachal Pradesh. The consumption of wild edible plants are used as supplements to cultivated crops and as a survival strategy during food shortages that appears to have been intensified due to low development of agricultural production. Tag and Das [11] documented the ethnobotanical importance of 28 plants species, which are particularly used as food, medicine, in rituals and other ethnobotanical importance of the Hills Miri tribe of Arunachal Pradesh. Deb et al [7] while studying the Nyishi ethnic community of Arunachal Pradesh reported that a large number of traditional crops grown in agro-forestry are valuable for the farmers' everyday life, as they provide a greater diversity of food and also act as a good source of commercial outlets in addition to household consumption. They also reported the importance of plant species like bamboo, Areca catechu and Livistonia jenkinsiana that are useful for fencing, craft making, house construction and valued for traditional worship as they are associated with ancestral sacrifices. Goswami et al [13] reported a total of 10 medicinal plants used by the Tagin tribe of Arunachal Pradesh for the treatment of common illness as well as for ethno-veterinary use. Utilization of this traditional knowledge of medicinal plants is not only useful for conservation of cultural traditions and biodiversity but also for community healthcare and drug development. Srivastava et al [14] reported a total of 106 plants species used in food, medicine, hunting, cultural and handicrafts by the Apatani tribe. Kagyung et al [15] reported a total of 44 plant species used by Adi tribe of Arunachal Pradesh for the treatment of various gastro-intestinal diseases. Sen et al [16] documented the traditional herbal knowledge of Khampti tribe of Arunachal and found the highest number of species used for treatment of lung related diseases. Sarmah et al [17] reported a total of 63 medicinal plant species used by Chakma community of Arunachal Pradesh for the treatment of common diseases such as diarrhea, malaria, cough, dysentery, and gastro-intestinal disorders. Dutta and Bhattacharjya [18] have studied an indigenous community fishing practiced by the Wancho tribe of Tirap district, Arunachal Pradesh.

Although the rich indigenous knowledge on the medicinal use of plants has been relatively well documented in other ethnic groups of Arunachal Pradesh [12-21], studies on the knowledge of medicinal and wild edible plants of Kalaktang Monpa are limited. In previous study, we reported that the Lohit community of Arunachal Pradesh have a rich knowledge on herbal remedies for treating inflammation-related diseases [21] and different tribes inhabiting in the state has a rich reservoir of traditional knowledge on natural resources.. The most serious threat to the existing knowledge and practice on traditional medicinal plants included cultural change, particularly the influence of modernization, lack of written document, deforestation, environmental degradation, and lack of interests shown by the next younger generations were the main problems reported by the informants during the field survey. Urgent ethno-botanical studies and subsequent conservation measures are required to prevent the loss of valuable indigenous knowledge of medicinal plants of several indigenous communities in Arunachal Pradesh. In the 
absence of modern rural link road and the lack of infrastructure in sub-health center in each villages covered in this study, the tribal communities primarily rely on plantbased remedies to meet their basic healthcare needs. Therefore, the assessment and documentation of ancestral knowledge of indigenous people on traditional plant medicines would fill the gap associated knowledge between the elders and the younger generation on medicinal plants. The purpose of this ethno-botanical study was to present the results of ethno-botanical field survey conducted between April 2006 and March 2009, which was analyzed with two different quantitative ethno-botanical tools to select the important species used in traditional medicine and the homogeneity of indigenous knowledge amongst Monpa ethnic group of Kalaktang, Arunachal Pradesh, India.

\section{Materials and methods Study area: Kalaktang}

The Kalaktang region (417 sq. km.) is located approximately between $91^{\circ} 30^{\prime}-92^{\circ} 40^{\prime}$ East longitudes and $26^{\circ}$ $54^{\prime}-28^{\circ} 01^{\prime}$ North latitudes with an estimated total population of 6,391 (male 3,318, female 3,073, total literacy $60.37 \%$, male $69.87 \%$ and female $48.12 \%$, Population Census, 2001). It shares an international border with the Tibet region of China in the North, Bhutan in the West, Tawang district and East Kameng districts of Arunachal are in the northwest and northeast, respectively. The southern boundary adjoins the Sonitpur district of Assam (Figure 1). The general topography of the region falls within the higher mountainous zone, cluster of tangled peaks and valleys intercepted by two major riverbedsNargum and Domkhorong and its large number of tributaries. The altitude of Kalaktang region is at $1113 \mathrm{~m}$ above sea level, the minimum and maximum temperature recorded ranged from $17.0^{\circ} \mathrm{C}$ to $31.5^{\circ} \mathrm{C}$, respectively. The average humidity is relatively high (75\%-80\%) during June-July months and it receives annual average rainfall of $674.50 \mathrm{~mm}$. Black, red, sandy and clay type soil predominate the entire study area. The vegetation of the area comprises of semi-evergreen, evergreen, deciduous, moist and temperate forests. The Kalaktang region comprises of 25 villages with only one community health center located at Kalaktang, a sub-center in each village covered in the present field work and a few villages are connected by a rural link road.

\section{Ethnology and cultural background: Monpa tribe}

The west kameng district is inhabited by five different tribes such as the Akas, Khowas, Mijis, Sherdukpens, and Monpa. The entire population of the west kameng district can be divided into two cultural groups on the basis of their socio-religious affinities, of which the Monpas and Sherdukpens follow the lamaistic tradition of Mahayana
Buddhism. The second groups of the people are Akas, Mijis, and Buguns, who worship the Sun and the Moon as God, locally called as "Donyi-Polo" and "Abo-Tani", respectively. Due to slight variations in dialects, Monpa can be divided into six linguistic groups, namely Tawang Monpa, Dirang Monpa, Lish Monpa, Boot Monpa, Panchen Monpa, and Kalaktang Monpa. The Monpa have castes and clans with no social hierarchy. Monogamy (follow strictly endogamy) is a general rules though polygamy is also practiced in the present generation. The Monpa belongs to the Tibeto-Mongoloid racial stock and their houses are built of stones and timber decorated with a small altars and chapels with statues of Lord Buddha. Offering water in seven little cups and burning butter lamps and some leaves of herbal species (Pinus wallichiana A.B. Jackson, Pinus longifolia Roxb. and Thuja occidentalis L.) are daily rituals. They believe in transmigration of soul and reincarnation. The Monpas perform many pantomime dances of which "Achilamu", a group of five member dance is the most unique and popular form of dance perform throughout the day to complete the process in special occasions. Festival forms essential aspects of socio-religious life of the Monpas. Lossar and Choskar are the major religious festival of Monpa celebrated once in a year. Lossar, usually celebrated in the month of March before the start of agriculture is the local new year of the Monpa community. In Choskar festival (celebrated after sowing crops like maize, paddy, etc), the lamas or Monks read religious scriptures in the Gonpa (monastery) for a number of days (3-4 days). Thereafter, the villager's particularly female folk (both married and unmarried) carry the religious books on their back in the procession under the guidance of senior most Monk and the procession (1 day) covers throughout the cultivation fields. The significance of this performance is to ensure bumper harvest and crop/grains protection from insects and wild animals and for overall prosperity of the village people. The Monpas are agriculturist, practice both shifting and permanent types of cultivation. The commonly grown field crops include maize, paddy, beans, bajra, millets, barley, wheat, mustard, cabbage, potato, cauliflower, and pumpkin, etc. Livestock's like yaks, cows, pigs, sheep, seasonal fishing, and hunting of wild animals are the primary source of income. The Monpas are well known for wood curving, painting religious scrolls called Thankas, carpet and paper making, and weaving.

\section{Ethno-botanical survey and consensus analysis}

A total of 27 field visits (8-10 days in each survey) were conducted amongst Monpa community during the study period from April 2006 and March 2009 to document an indigenous traditional knowledge on medicinal plants. Male and female respondents with age ranging from 20-60 years were included during interview. All collections were 


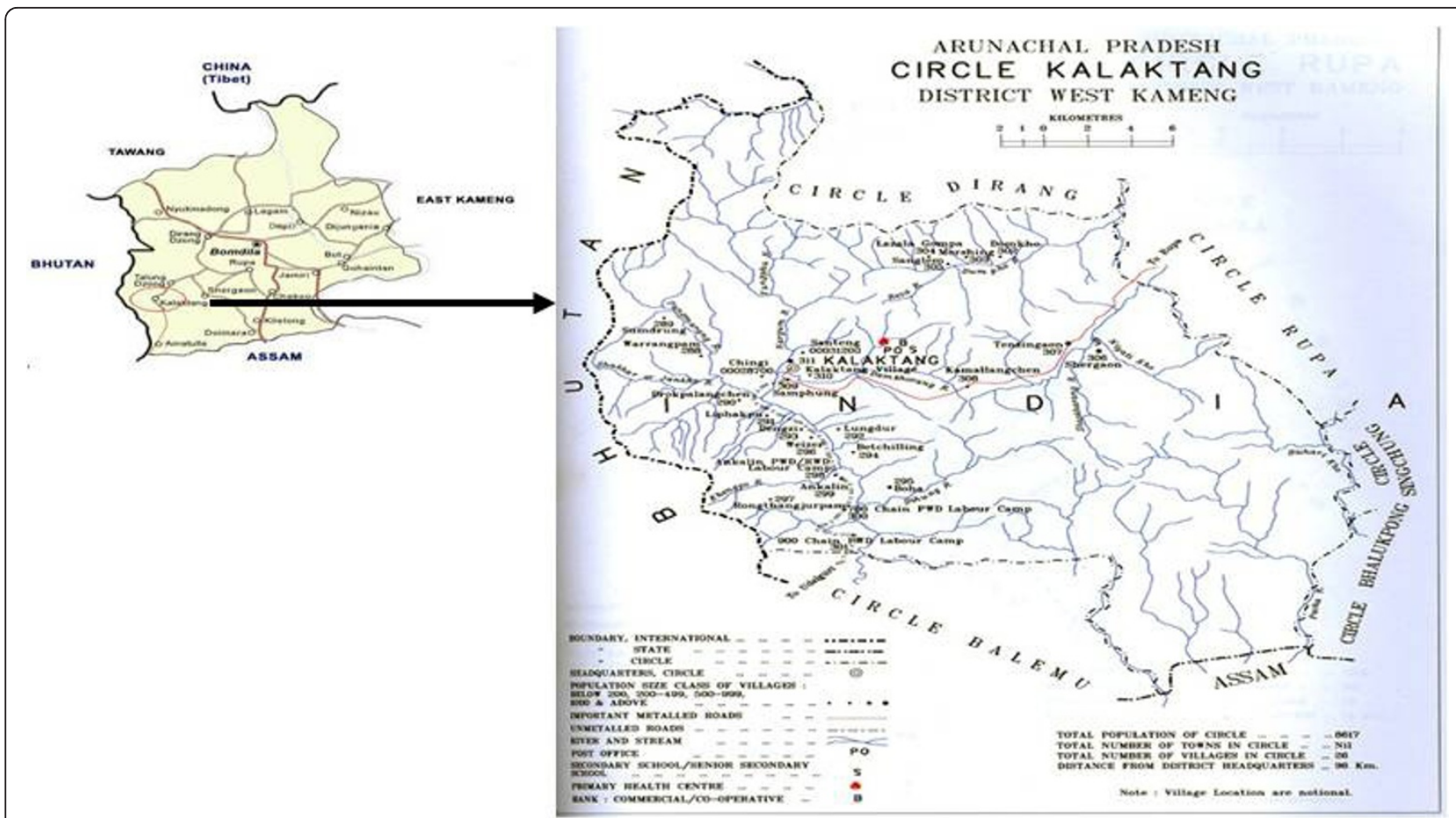

Figure 1 A detailed study map of study area Kalaktang showing the geographical locations of villages covered during the field work

made by the first author (NDN) who grew up and belonged to Monpa community of Kalaktang and was familiar with the local language and some of the traditional plants used by the local people of the region. The ethno- botanical information was collected using semistructured questionnaires $[21,22]$ to address the following objectives:

1. Document the medicinal plants used in the traditional healthcare system of Kalaktang study area-parts used and method of preparation,

2. The informant consensus factor $\left(\mathrm{F}_{\mathrm{IC}}\right)$ was calculated in order to estimate use variability of medicinal plants,

3. Reliability of medicinal plant was assessed by comparing indigenous plant use with online literature reports on phytochemical and pharmacological properties,

4. How is the traditional knowledge of indigenous people preserved, utilized and transmitted to next generation?

Only the plants indicated by at least 20 independent informants were considered. The acquired data were confirmed by repeated queries and field surveys made among the general local people, experienced elderly people and 20 male respondents that constitute the traditional herbal practitioners. The taxonomic identification of the collected plant specimens was made with the help of herbarium materials, experts and taxonomic keys at Botanical Survey of India, Arunachal Pradesh. The botanical nomenclature followed that of the Flora of Arunachal Pradesh [23-25]. The voucher specimens were deposited in the Department of Molecular Biology and Biotechnology, Tezpur University for future reference. Calculation of a consensus factor $\left(\mathrm{F}_{\mathrm{IC}}\right)$ for testing homogeneity on the informant's knowledge was followed by the method provided by Trotter and Logan [26]. A consensus factor of $F_{I C}$ is given by:

$$
\mathrm{F}_{\mathrm{IC}}=\mathrm{N}_{\mathrm{ur}}-\mathrm{N}_{\mathrm{t}} /\left(\mathrm{N}_{\mathrm{ur}}-1\right)
$$

The factor provides a range of 0 to 1 , where a high value acts as a good indicator for a high rate of informant consensus. $\mathrm{N}_{\mathrm{ur}}$ is the number of use-reports of informants for particular illness usage, where a use-report is a single record for use of a plant mentioned by an individual, and $\mathrm{N}_{\mathrm{t}}$ refers to the number of species used for a particular illness category for all informants. The use of "general categories" is adopted here as recommended by other ethnobotanical researchers $[27,28]$. These 22 illnesses were clustered into 4 usage (dermatological, gastro-intestinal, general health and miscellaneous disorders) categories (Table 1).

\section{Results and discussion}

\section{Medicinal plants, growth forms and plant parts}

This study identified fifty ethnobotanical species, 36 species $(60 \%)$ were used as herbal medicines for treating 22 different human ailments. Some of the reported plants were used for other functions: rituals (14\%) and religions, fish feeds and poisoning (10\%), veterinary healthcare (7\%) and local beverage or fermentation purpose (7\%). 


\section{Table 1 Ethnobotanical consensus index for traditional medicinal plant use categories}

\begin{tabular}{|c|c|c|c|}
\hline Illness category (diseases and disorders) & $\begin{array}{l}\text { Number of } \\
\text { Taxa }\left(\mathrm{N}_{\mathrm{t}}\right)\end{array}$ & $\begin{array}{l}\text { Number of use- } \\
\text { reports }\left(\mathrm{N}_{\mathrm{ur}}\right)\end{array}$ & $\begin{array}{l}\text { Informants' consensus } \\
\text { index factor }\left(F_{I C}\right)^{a}\end{array}$ \\
\hline $\begin{array}{l}\text { Dermatological disorder (Scabies, skin diseases, pimples, eczema, } \\
\text { inflammations, wound healing, cuts) }\end{array}$ & 15 & 34 & 0.56 \\
\hline $\begin{array}{l}\text { Gastro-intestinal disorder (Gastritis, diarrhea, dysentery, stomach ache, } \\
\text { intestinal worms, and throat clearance) }\end{array}$ & 21 & 36 & 0.43 \\
\hline $\begin{array}{l}\text { General Health (Tooth ache, bone fracture, heart problem, cough, diabetes, } \\
\text { high blood pressure, and jaundice) }\end{array}$ & 9 & 11 & 0.20 \\
\hline $\begin{array}{l}\text { Miscellaneous (Poison, veterinary diseases, beverages, rituals and religious, } \\
\text { fodder, condiments, and soap) }\end{array}$ & 24 & 29 & 0.17 \\
\hline
\end{tabular}

${ }^{a} F_{\mathrm{IC}}=\mathrm{N}_{\mathrm{ur}}-\mathrm{N}_{\mathrm{t}} /\left(\mathrm{N}_{\mathrm{ur}}-1\right)$, providing a value between 0 and 1 , where high value indicates a high rate of informant consensus.

The surveyed plants contained the following ethnobotanical elements: botanical name, voucher specimen number, local name, parts used, and method of preparations and ailments treated (Table 2). The families Asteraceae and Solanaceae had six and three species, respectively. Most of the ethnobotanical plants (50 species in this study) were herbs $(40 \%)$, shrubs $(28 \%)$, trees (26\%), and climbers (6\%). This study recorded that several parts of individual plant species were used as a medicine. The use of aerial plant parts (91\%) was higher than the underground plant parts (9\%). Leaves (53\%) were predominantly used as a remedy followed by the fruit/seed/ pod $(26 \%)$, whole plant $(9 \%)$, rhizome $(6 \%)$, tuber $(3 \%)$, and flower $(3 \%)$. The preference for leaf has also been recorded amongst the Kani communities in India [29], the Malasars of Dravidian Tamils occupying the forests of the Western Ghats, South India [30] and the traditional Tibetan doctors (Amchi) of Mustang district of the north-central part of Nepal [31]. The common use of herbs as sources of medicine found in this study were also indicated by studies conducted elsewhere [29-32].

\section{Consensus of traditional knowledge}

This study indicates a high level of consensus within the Monpa ethnic community. In our study, the informant consensus of medicinal plant usage with the Monpa ethnic group resulted in $\mathrm{F}_{\mathrm{IC}}$ factors ranging from 0.17 to 0.56 per illness category (Table 1). The consensus analysis revealed that the category dermatological disorders have the highest $\mathrm{F}_{\mathrm{IC}}$ factor of 0.56 and the gastro-intestinal diseases have intermediate $\mathrm{F}_{\mathrm{IC}}(0.43)$, indicating greater homogeneity among informants. The highest $\mathrm{F}_{\mathrm{IC}}$ value for dermatological and gastro-intestinal diseases categories could be related to the high occurrence of skin-related and gastritis problems in the study area. The $F_{I C}$ of local knowledge for disease treatment depended on the availability of plant species and the occurrence of diseases in the study area. In the literature, high informant consensus $\left(F_{I C} 0.875\right)$ was also recorded among the snakebite healers of Kamba in Africa [33] and treating 'mich' or febrile diseases $\left(\mathrm{F}_{\mathrm{IC}} 0.80\right)$ among Northwestern Ethiopia [34]. The fidelity value (FL) of a plant species for a specific disease in the study area varied between 30 and 100\%. The maximum FL of 100\% expressed by Artemisia nilagirica, Azadirachta indica, Allium sativum, Cannabis sativa, Clerodendrum colebrookianum, Gymnocladus assamicus, Lindera neesiana, Ocimum sanctum, Psidium guajava, and Saccharum officinarum, for wound healing and scabies, stomach disorder and diarrhea, bone fracture, diarrhea in cattle, high blood pressure, soap and ethno-veterinary, intestinal worms, wounds, diarrhea, and jaundice, respectively, indicated the $100 \%$ choice of most healers or plant practitioners for treating such diseases. The literature search on ethnopharmacological use showed that many of the species of plants with $100 \%$ FL were used to treat ailments in other parts of the world (See Table 3). A specific example includes Artemisia nilagirica [35], Azadirachta indica [36], Allium sativum [37], Clerodendrum colebrookianum [38-40], Gymnocladus assamicus [41,42]Lindera neesiana [43], Ocimum sanctum [44], Psidium guajava [45-47], Momordica charantia [48,49], and Rhododendron arboreum [50]. However, the pharmacological properties of an individual plant can be significantly altered in the presence of other plant species in compound medicines. Psidium guajava is one of the most recorded plant species used to treat diarrhoea in developed countries [45]. On the other hand, the lowest FL of $30 \%$ indicated less preferred species by the traditional healers for treating specific ailment. For example, Eupatorium adenophorum was used for treating freshly cuts and wounds; Houttuynia cordata was used for treating stomach ache and diarrhea.

\section{Comparison of indigenous plant use with available pharmacological reports}

An empirical observation on the use of medicinal plants by the Monpa people of Kalaktang study area requires cross-validation with published literatures on phytochemical and pharmacological properties of medicinal plants reported in this study to corroborate their bioefficacy. Literature review for 27 medicinal plant species revealed that the reported local use was coherent with known pharmacological properties (See Table 4). 
Table 2 Ethno-botanical uses of plants documented in the study area: Kalaktang, Arunachal Pradesh

\begin{tabular}{|c|c|c|c|c|c|c|}
\hline $\begin{array}{l}\text { Botanical name/Voucher } \\
\text { number }\end{array}$ & Family name & $\begin{array}{l}\text { Local name/Status of } \\
\text { domestication }\end{array}$ & Habit & Parts used & Herbal formulation & Ailments treated \\
\hline $\begin{array}{c}\text { Artemisia nilagirica (Clarke) Pamp. } \\
\text { (N/2005-20) }\end{array}$ & Asteraceae & Merangma, Wild & Sh & Leaves & Juice and paste (E) & Wounds, cuts, scabies, and inflammations \\
\hline $\begin{array}{l}\text { Ageratum conyzoides Linn. (N/ } \\
\text { 2005-21) }\end{array}$ & Asteraceae & Ngonamshu, Wild & $\mathrm{H}$ & Leaves & Juice and paste (E) & Wound healer, Veterinary, fish poison \\
\hline $\begin{array}{l}\text { Azadirachta indica A. Juss (N/ } \\
\text { 2006-2001) }\end{array}$ & Meliaceae & Neem, Wild & T & Leaves & Decoction (I) & Stomach disorder, diarrhoea \\
\hline Allium sativum Linn. (N/2006-200) & Liliaceae & Chong, Cult & $\mathrm{H}$ & $\begin{array}{l}\text { Leaves and } \\
\text { rhizome }\end{array}$ & Paste and juice (E) & Bone fracture \\
\hline Allium hookeri Linn. (N/2005-22) & Liliaceae & Lam, Cult & $\mathrm{H}$ & $\begin{array}{l}\text { Leaves and } \\
\text { rhizome }\end{array}$ & Paste and juice (E) & Skin diseases, Veterinary, bone fracture, \\
\hline $\begin{array}{l}\text { Aesculus assamica Griffith (N/2005- } \\
40)\end{array}$ & Sapindaceae & Thretangshing, Wild & T & Stem bark & $\begin{array}{l}\text { Fresh barks collected and pounded with } \\
\text { wooden stick }\end{array}$ & Fish poison \\
\hline Aconitum ferox Wall. (N/2005-46) & Ranunculaceae & Shaga-manshing, Wild & $\mathrm{H}$ & Tuber & Paste in arrow (made of iron) poisoning & Poison to kill rats and wild animals \\
\hline Bidens pilosa Linn. (N/2006-222) & Asteraceae & Robashing, Wild & $\mathrm{H}$ & Leaves & Decoction and paste (E) & Wounds and skin inflammations \\
\hline $\begin{array}{l}\text { Buddleja asiatica Lour. (N/2006- } \\
\text { 223) }\end{array}$ & Scrophulariaceae & Phamshing, Wild & Sh & $\begin{array}{l}\text { Leaves and } \\
\text { young twigs }\end{array}$ & Juice and paste (E) & Diarrhoea, Beverages fermentation \\
\hline Cannabis sativa Linn. (N/2005-19) & Urticaceae & Namku, Wild & Sh & $\begin{array}{l}\text { Leaves and } \\
\text { seeds }\end{array}$ & Mixed with maize flour & Veterinary \\
\hline $\begin{array}{c}\text { Castanopsis indica Roxb (N/2005- } \\
38)\end{array}$ & Fagaceae & Kheshing, Wild & T & $\begin{array}{l}\text { Leaves and } \\
\text { stem bark }\end{array}$ & Whole plant extract is used to poison fish & Fish poison and raw seeds are eaten \\
\hline Curcuma caesia Roxb. (N/2005-28) & Zingibaraceae & Yongka, Cult & $\mathrm{H}$ & Rhizome & Paste (E) & Rituals and pimples removal \\
\hline $\begin{array}{l}\text { Centella asiatica Linn. (N/2006- } \\
\text { 224) }\end{array}$ & Apiaceae & Manimuni, Cult & $\mathrm{H}$ & Whole plant & Decoction (I), vegetable & $\begin{array}{l}\text { Stomach disorder, cuts, wounds, } \\
\text { inflammations\& common vegetable }\end{array}$ \\
\hline $\begin{array}{l}\text { Clerodendrum colebrookianum } \\
\text { Walp. (N/2005-24) }\end{array}$ & Verbenaceae & Khangjela-shing, Wild & Sh & Leaves & Decoction with sugar (I), boiled vegetable & $\begin{array}{l}\text { High blood pressure, stomach disorder, } \\
\text { headache }\end{array}$ \\
\hline Citrus indica Tanaka (N/2005-25) & Rutaceae & Tsalum, Cult & T & Fruit/seeds & Paste (E) & Face pimples removal \\
\hline Dioscorea alata Linn. (N/2005-23) & Dioscoreaceae & Rangthangong, Cult & C & Tuber & Boiled vegetable & Gastritis \\
\hline $\begin{array}{l}\text { Derris scandens (Roxb.) Benth. (N/ } \\
\text { 2005-32) }\end{array}$ & Leguminaceae & Sa-ngairushing, Wild & C & Roots & $\begin{array}{l}\text { Roots are pounded with wooded stick and } \\
\text { thrown into the river to poison fishes }\end{array}$ & Community fishing \\
\hline Ficus glomerata Roxb. (N/2005-30) & Moraceae & Koknangshing, Wild & T & Fruits/seeds & Eaten raw & Diabetes and common fodder \\
\hline $\begin{array}{c}\text { Gynura crepedioides (BTH.) Moore } \\
\text { (N/2006-225) }\end{array}$ & Asteraceae & Jakpangon, Wild & $\mathrm{H}$ & $\begin{array}{l}\text { Leaves and } \\
\text { young twigs }\end{array}$ & Boiled vegetable/raw & Vegetables and stomach disorder \\
\hline $\begin{array}{l}\text { Gymnocladus assamicus Kanjilal ex. } \\
\text { P.C. Kanjilal (N/2005-17) }\end{array}$ & Fabaceae & Minangmashing, Wild & T & Mature pods & Bark & Detergent (soap), religious and veterinary \\
\hline $\begin{array}{l}\text { Hedyotis scandens Roxb. (N/2006- } \\
\text { 228) }\end{array}$ & Rubiaceae & Phamshing, Wild & Sh & $\begin{array}{l}\text { Leaves and } \\
\text { young twigs }\end{array}$ & Decoction with sugar (I) & Gastritis, Beverages fermentation \\
\hline $\begin{array}{l}\text { Houttuynia cordata Thunb. (N/ } \\
\text { 2006-229) }\end{array}$ & Piperaceae & Momarengpa, Wild & $\mathrm{H}$ & Whole plant & Decoction (I)/boiled vegetable/raw & Stomachache and diarrhoea \\
\hline $\begin{array}{l}\text { Ipomoea batatas Linn. (Lam.) (N/ } \\
\text { 2005-35) }\end{array}$ & Convolvulaceae & Yengjoktang, Cult & $\mathrm{H}$ & $\begin{array}{l}\text { Leaves and } \\
\text { tuber }\end{array}$ & Boiled vegetable & $\begin{array}{l}\text { Rituals, tubers staple food and leaves as fish } \\
\text { feeds }\end{array}$ \\
\hline Leucas aspera Spreng. (N/2006- & Lamiaceae & Ngonshing, Wild & $\mathrm{H}$ & Leaves & Juice and paste (E) & Cuts and wounds, earache, inflammation \\
\hline
\end{tabular}


Table 2 Ethno-botanical uses of plants documented in the study area: Kalaktang, Arunachal Pradesh (Continued)

\begin{tabular}{|c|c|c|c|c|c|c|}
\hline $\begin{array}{l}\text { Litsea cubeba (Lour) Pers. (N/2005- } \\
\text { 38) }\end{array}$ & Lauraceae & Nengshing, Wild & T & Fruits & Paste (E), Raw/cooking & $\begin{array}{l}\text { Condiments, eczema, heart disease and } \\
\text { stomach disorder }\end{array}$ \\
\hline $\begin{array}{c}\text { Lindera neesiana (Wallich ex Nees) } \\
\text { Kurz (N/2005-39) }\end{array}$ & Lauraceae & Lungkarmashing, Wild & T & Fruits/Seeds & Hot oils taken 2-3 spoonful (I) & $\begin{array}{c}\text { Anthelmintic, diarrhoea, scabies, vegetable } \\
\text { oils }\end{array}$ \\
\hline $\begin{array}{l}\text { Momordica charantia Linn. (N/ } \\
\text { 2006-236) }\end{array}$ & Cucurbitacaea & Kairu, Cult & C & Fruit/Seeds & Cooking/raw & Anthelmintic, diabetes \\
\hline $\begin{array}{c}\text { Mannihot esculenta Crantz (N/ } \\
\text { 2006-238) }\end{array}$ & Euphorbiaceae & Shingjoktang, Cult & Sh & Rhizome & Cooking & Rituals, vegetables \\
\hline $\begin{array}{l}\text { Oroxylum indicum Vent. (N/2006- } \\
\text { 240) }\end{array}$ & Bignoniaceae & Namkalingshing, Cult & T & Fruits/seeds & Seeds collected and dried & Rituals \\
\hline $\begin{array}{l}\text { Ocimum sanctum Linn. (N/2006- } \\
\text { 244) }\end{array}$ & Lamiaceae & Tilosi, Cult & $\mathrm{H}$ & Leaves & Paste (E), hot water decoction (I) & $\begin{array}{c}\text { Stomach disorder, inflammations, wounds, } \\
\text { cuts }\end{array}$ \\
\hline $\begin{array}{l}\text { Pinus wallichiana A.B. Jackson (N/ } \\
\text { 2005-16) }\end{array}$ & Pinaceae & Chhu-gon-shing, Wild & T & $\begin{array}{l}\text { Leaves and } \\
\text { cones }\end{array}$ & & Rituals and resins \\
\hline Pinus longifolia Roxb (N/2005-15) & Pinaceae & Chhu-gon-shing, Wild & T & Leaves & & Ritual \\
\hline Piper betle Linn. (N/2005-14) & Piparaceae & Unknown, Cult & $\mathrm{H}$ & Leaves & & Beverages fermentation \\
\hline $\begin{array}{l}\text { Polygonum hydropiper Linn. (N/ } \\
\text { 2005-36) }\end{array}$ & Polygonaceae & Ngashing, Wild & $\mathrm{H}$ & Whole plant & Whole plant extract & Fish poison \\
\hline $\begin{array}{l}\text { Psidium guajava Linn. (N/2006- } \\
\text { 252) }\end{array}$ & Myrtaceae & Baghanse, Cult & T & Leaves & Raw/decoction with citrus fruit juice and salt (I) & Darrhoea, cough \\
\hline $\begin{array}{l}\text { Punica granatum Linn. (N/2005- } \\
\text { 37) }\end{array}$ & Punicaceae & Dalemshing, Cult & $\mathrm{H}$ & Leaves & Decoction & Stomach ache and diarrhoea \\
\hline $\begin{array}{l}\text { Pouzolzia bennettiana Wight (N/ } \\
\text { 2005-52) }\end{array}$ & Urticaceae & Oyek, Wild & Sh & Leaves & Boiled vegetable & Stomach disorder \\
\hline Plantago major Linn. (N/2005-42) & Plantaginaceae & Tsashing, Wild & $\mathrm{H}$ & Whole plant & Paste and juice (E) & Wounds, inflammations, Veterinary \\
\hline $\begin{array}{l}\text { Rhododendron arboreum Smith. } \\
\text { Gurans (N/2005-49) }\end{array}$ & Ericaceae & Woodongmento, Wild & T & Flower & Decoction with sugar (I) & $\begin{array}{l}\text { Dysentery, diarrhoea, throat clearance when } \\
\text { fish bones get stuck in the gullet }\end{array}$ \\
\hline $\begin{array}{l}\text { Solanum xanthocarpum Burm. f. } \\
\text { (N/2005-44) }\end{array}$ & Solanaceae & Zubalemin, Wild & $\mathrm{H}$ & Seeds & Paste (I) & Dental problem \\
\hline $\begin{array}{l}\text { Solanum indicum Linn. (N/2005- } \\
54)\end{array}$ & Solanaceae & Kharangeh, Cult & Sh & Seeds & Boiled vegetable/raw & Anthelmintic, Beverages fermentation \\
\hline Solanum torvum Sw. (N/2005-50) & Solanaceae & $\begin{array}{l}\text { Borang Kharangjeh, } \\
\text { Wild }\end{array}$ & Sh & Seeds & Boiled vegetable/raw & Anthelmintic \\
\hline Solanum sp. (N/2005-13) & Solanaceae & Apataniseh, Wild & Sh & Seeds & Boiled vegetables/raw & Antihelminthic \\
\hline $\begin{array}{l}\text { Saccharum officinarum Linn. (N/ } \\
\text { 2006-243) }\end{array}$ & Poaceae & Khumin, Cult & Sh & Stem & Juice (I) & Jaundice \\
\hline $\begin{array}{l}\text { Spilanthes oleracea Murr. (N/2006- } \\
\text { 246) }\end{array}$ & Asteraceae & Marshang, Wild & $\mathrm{H}$ & $\begin{array}{l}\text { Leaves and } \\
\text { young twigs }\end{array}$ & Paste (E)/boiled vegetable & $\begin{array}{l}\text { Stop bleeding, skin infections and gastritis, } \\
\text { fish poison }\end{array}$ \\
\hline $\begin{array}{l}\text { Thysanolaena maxima Kuntze (N/ } \\
\text { 2006-250) }\end{array}$ & Poaceae & $\begin{array}{l}\text { Tsakpushabashing, } \\
\text { Wild }\end{array}$ & Sh & Whole plant & Whole plant collected and dried & Rituals \\
\hline $\begin{array}{l}\text { Thuja occidentalis Linn. (N/2005- } \\
\text { 12) }\end{array}$ & Cupressaceae & Pos-shing, Wild & Sh & Whole plant & & Rituals \\
\hline $\begin{array}{l}\text { Zingiber officinale Rosc. (N/2005- } \\
\text { 48) }\end{array}$ & Zingiberaceae & Saagha,Cult & $\mathrm{H}$ & Rhizome & Raw/vegetable & Cough and Stomachache \\
\hline
\end{tabular}


Table 3 Fidelity Level (FL) of interesting medicinal plants of the study area

\begin{tabular}{|c|c|c|c|}
\hline Plants & Illness categories & $\begin{array}{l}\text { Fidelity level (FL) } \\
(\%)\end{array}$ & $\begin{array}{l}\text { Published related ethno-pharmacological } \\
\text { references }\end{array}$ \\
\hline Artemisia nilagirica & Wound healing, scabies & 100 & Antifungal activity [22] \\
\hline Azadirachta indica & Stomach disorder, diarrhea & 100 & Antibacterial and antidiarrhoeal activity[23] \\
\hline Allium sativum & Bone fracture & 100 & Anti-inflammatory activity [24] \\
\hline Cannabis sativa & Diarrhea in cattle & 100 & \\
\hline $\begin{array}{l}\text { Clerodendrum } \\
\text { colebrookianum }\end{array}$ & High blood pressure & 100 & Remedy for treatment of hypertension [25-27] \\
\hline Gymnocladus assamicus & Soap, ethnoveterinary & 100 & Soap/detergent substitute $[28,29]$ \\
\hline Lindera neesiana & Intestinal worms & 100 & Essential oil [30] \\
\hline Ocimum sanctum & Stomach disorder, wounds & 100 & $\begin{array}{r}\text { Wound healing activity; Gastro-protective; Flavanoids } \\
\qquad 31]\end{array}$ \\
\hline Psidium guajava & Diarrhea & 100 & Antidiarrhoeal, Antibacterial activity [32-34] \\
\hline Saccharum officinarum & Jaundice & 100 & \\
\hline Momordica charantia & Intestinal worms, diabetes & 80 & Anti-diabetic activity, triterpenoids $[35,36]$ \\
\hline Solanum xanthocarpum & Dental problem & 80 & \\
\hline Rhododendron arboreum & Diarrhea, throat clearance & 78 & Quercetin, rutin, coumaric acid [37] \\
\hline Plantago major & $\begin{array}{l}\text { Wounds, inflammations, } \\
\text { ethnoveterinary }\end{array}$ & 68.85 & \\
\hline Zingiber officinale & Cough and throat clearance & 67 & \\
\hline Ageratum conyzoides & Wound healer & 60 & \\
\hline Solanum etiopicum & Intestinal worms & 56 & \\
\hline Solanum indicum & Intestinal worms & 48 & \\
\hline Eupatorium adenophorum & Freshly cuts and wounds & 30 & \\
\hline Houttuynia cordata & Stomach ache, diarrhea & 30 & \\
\hline
\end{tabular}

Comparison of the information on traditional medicinal plant use of Monpa ethnic group with ethnobotanical studies conducted in other ethnic communities of Arunachal Pradesh [11-18] shows similar results for many species. This is of significance because identical plant use by several communities' from different areas may be a reliable indication of curative properties.

\section{Traditional knowledge secrecy and method of crude herbal medicine preparation}

A total of 50 plant species belonging to 29 families and 39 genera were reportedly used by the Monpa ethnic group in their daily life. One hundred twenty-four informants (91 male and 33 female individuals) were interviewed in the study area with their age ranged between 20-60 years. Large number of informants reported that most ailments were treated at a household level. On average, significantly higher numbers of medicinal plants were claimed by illiterate village men than women (91 (73.4\%) men; 33 (26.6\%) women; aged between 40 and 60 years). Ethno-pharmacological survey work in India also indicated that information on the medicinal uses of plants was being confined mostly to elderly people (above 40 years of age) $[46,47]$. Literate people in the study area reported less number of medicinal plants as compared to illiterate ones which could probably be due to higher influence of modernization on the former. This observation holds true for related studies conducted throughout the world [48-50]. However, a study conducted by the Fassil [51] in the Northwestern Ethiopia, revealed that there was no significant difference in medicinal plant knowledge between men and women. Twenty-one male respondents (aged between 48-60 years) constitute knowledgeable, whose tradition of healing practices are revered and trusted in the local community and play multiple roles as spiritual guides and healers. Many ailments have been diagnosed and treated at household or family level and the fact that most treatments are given at household level was also reflected in the findings of other works [52-56]. There was high agreement among informants that transfer of knowledge to people outside the family circle took place on substantial payment. Most informants reported that knowledge was formally transferred along the family line and mainly through sons [57-62]. Remedy preparations often involved some sort of spiritual or ritual procedures. Ethno-pharmacological survey work conducted elsewhere demonstrated similar results [[13,45], and [46]]. This is also evident from Ethiopia where parents prefer to pass their traditional medical knowledge secrecy more to sons than to daughters [47]. Nearly $90 \%$ of informants reported that vertical transfer of medicinal plant knowledge was not taking place effectively due to lack of interest by the younger generation to learn and practice it mainly due to acculturation. It was also revealed that some informants ceased to practice traditional medicine due to the increasing 
Table 4 Comparison of indigenous plant use and pharmacological properties of reported medicinal plants Species name Indigenous use Reported phytochemical/pharmacological properties

\begin{tabular}{|c|c|c|c|}
\hline $\begin{array}{l}\text { Artemisia } \\
\text { nilagirica }\end{array}$ & $\begin{array}{l}\text { Wounds, scabies, } \\
\text { inflammations }\end{array}$ & Anti-microbial, anti-fungal activity and polyphenolic compounds $[64,65]$. & Yes \\
\hline $\begin{array}{l}\text { Ageratum } \\
\text { conyzoides }\end{array}$ & Wound healer & $\begin{array}{l}\text { Anti-inflammatory, analgesic, anti-pyretic, anti-microbial, and wound } \\
\text { healing properties }[66,67] \text {. Tannins, saponins, coumarins, flavonoids, } \\
\text { pyrrolizidine alkaloids }[68] .\end{array}$ & Yes \\
\hline $\begin{array}{l}\text { Azadirachta } \\
\text { indica }\end{array}$ & $\begin{array}{l}\text { Stomachache, } \\
\text { diarrhoea }\end{array}$ & $\begin{array}{l}\text { Anti-inflammatory, anti-pyretic, analgesic, anti-ulcerogenic properties } \\
{[69,70] \text {. }}\end{array}$ & Yes \\
\hline Allium sativum & Bone fracture & Anti-inflammatory in experimental rats [71]. & Yes \\
\hline Bidens pilosa & Wounds healer & $\begin{array}{l}\text { Anti-inflammatory, anti-allergic activity (Horiuchi and Seyama, 2008; } \\
\text { Inflammations, bacterial infections [72]. }\end{array}$ & Yes \\
\hline $\begin{array}{l}\text { Centella } \\
\text { asiatica }\end{array}$ & $\begin{array}{l}\text { Stomach disorder, } \\
\text { wounds }\end{array}$ & $\begin{array}{l}\text { Anti-inflammatory activity, wound healing activity of asiaticoside [73]. } \\
\text { Triterpenicconstituents asiaticoside, asiatic acid andmadecassic acid } \\
\text { [74]. }\end{array}$ & Yes \\
\hline $\begin{array}{l}\text { Clerodendrum } \\
\text { colebrookianum }\end{array}$ & $\begin{array}{l}\text { High blood } \\
\text { pressure }\end{array}$ & Used for high blood pressure $[75,76]$ & Yes \\
\hline Dioscorea alata & Gastritis & No relevant report found & \\
\hline Ficus glomerata & Diabetes & Hypoglycemic activity in alloxan-induced diabetic rats [77]. & Yes \\
\hline $\begin{array}{l}\text { Gynura } \\
\text { crepedioides }\end{array}$ & Stomach disorder & No relevant report found & \\
\hline $\begin{array}{l}\text { Hedyotis } \\
\text { scandens }\end{array}$ & Gastritis & No relevant report found & \\
\hline Leucas aspera & $\begin{array}{l}\text { Wounds, earache, } \\
\text { inflammation }\end{array}$ & Antimicrobial activity [78]. Leucasin and anti-oxidant activity [79]. & Partial \\
\hline Litsea cubeba & $\begin{array}{l}\text { Eczema, stomach } \\
\text { disorder }\end{array}$ & Fungicidal terpenoids and essential oil [80]. & Partial \\
\hline $\begin{array}{l}\text { Lindera } \\
\text { neesiana }\end{array}$ & $\begin{array}{l}\text { Anthelmintic, } \\
\text { diarrhoea }\end{array}$ & Essential oil and antimicrobial activity [81]. & Partial \\
\hline $\begin{array}{l}\text { Momordica } \\
\text { charantia }\end{array}$ & $\begin{array}{l}\text { Anthelmintic, } \\
\text { diabetes }\end{array}$ & Anti-diabetic activity [82]. & Yes \\
\hline $\begin{array}{l}\text { Ocimum } \\
\text { sanctum }\end{array}$ & $\begin{array}{l}\text { Stomachache, } \\
\text { inflammations, } \\
\text { wounds }\end{array}$ & $\begin{array}{l}\text { Anti-oxidant and wound healing activity [83]. Leaf paste applied on } \\
\text { infected skin [84]. }\end{array}$ & Yes \\
\hline $\begin{array}{l}\text { Psidium } \\
\text { guajava }\end{array}$ & Diarrhoea, cough & Anti-diarrhoea activity [85]. & Yes \\
\hline $\begin{array}{l}\text { Punica } \\
\text { granatum }\end{array}$ & $\begin{array}{l}\text { Stomach ache, } \\
\text { diarrhoea }\end{array}$ & Antidiarrhoeal and anti-inflammatory activity [86]. & Yes \\
\hline $\begin{array}{l}\text { Pouzolzia } \\
\text { bennettiana }\end{array}$ & Stomach disorder & No relevant report found & \\
\hline Plantago major & $\begin{array}{l}\text { Wounds, } \\
\text { inflammations }\end{array}$ & Anti-inflammatory, wound healing, anti-microbial, anti-tumor [87]. & Yes \\
\hline $\begin{array}{l}\text { Rhododendron } \\
\text { arboreum }\end{array}$ & $\begin{array}{l}\text { Dysentery, } \\
\text { diarrhoea }\end{array}$ & $\begin{array}{l}\text { Quercetin, rutin and coumaric acid [53]. Protective effect against } \\
\text { carbon tetrachloride-induced hepatotoxicity in experimental models } \\
\text { [88]. }\end{array}$ & No \\
\hline $\begin{array}{l}\text { Solanum } \\
\text { xanthocarpum }\end{array}$ & Dental problem & No relevant report found & \\
\hline $\begin{array}{l}\text { Solanum } \\
\text { indicum }\end{array}$ & Anthelmintic & Cytotoxic and novel compounds [89]. & No \\
\hline $\begin{array}{l}\text { Solanum } \\
\text { torvum }\end{array}$ & Anthelmintic & Anthelmintic activity of botanical extracts [90]. & Yes \\
\hline $\begin{array}{l}\text { Saccharum } \\
\text { officinarum }\end{array}$ & Jaundice & $\begin{array}{l}\text { Sugar cane contains phenolic acids, flavonoids and other phenolic } \\
\text { compounds [91]. }\end{array}$ & No \\
\hline $\begin{array}{l}\text { Spilanthes } \\
\text { oleracea }\end{array}$ & $\begin{array}{l}\text { Stop bleeding, } \\
\text { gastritis }\end{array}$ & No relevant report found & \\
\hline $\begin{array}{l}\text { Zingiber } \\
\text { officinale }\end{array}$ & $\begin{array}{l}\text { Cough, } \\
\text { Stomachache }\end{array}$ & Antibacterial activity [92]. & Partial \\
\hline
\end{tabular}


availability of allopathic medicines. Informants in the study area confirmed that, medicinal plants are generally collected from different habitats. The method of preparation was mostly a hot water decoction in case of plants being administered orally and usually prepared from freshly collected plant material just before use. Studies conducted elsewhere $[40,47]$ also revealed the frequent use of fresh materials. Fresh materials are also preferred to dried ones when they contain volatile oils, the concentration of which could deteriorate on drying. The majority of remedies were administered topically or external (16 species) or hot water decoction or oral administration ( 9 species), boiled vegetable (12 species), and eaten raw (9 species, see Table 2 ). Remedies were mostly processed using locally made mortar and pestle or grinders. Plant material used for preparation of herbal remedies was difficult to quantify but was indicated approximately 40-50 g fresh plant material or 20-25 $\mathrm{g}$ of powdered plant material in $300 \mathrm{ml}$ of hot water to be taken twice daily after meal. Doses were mainly taken twice a day because most people were present at home on the morning and evening. The dosage depends on the age and physical appearance of the individual whilst children's were given less than adults which approximate to 100-150 $\mathrm{ml}$ twice daily depending on the type of illness and treatment. There were no reports of side effects following administration of herbal remedies as informed by the treated patients in particular and the local practitioners. Treatment was supposed to be continued until recovery. When patients did not show any sign of improvement after the completion of treatments with herbal remedies, they were taken to a nearby modern health centers for further examination by the physician. The ethno-botanical knowledge of Monpa ethnic group gathered in this study has been categorized and described briefly in the following subheadings.

\section{Edible plants used as vegetables}

The Monpa community derives common vegetables either alone or in combination from underexploited plant species like Alocasia indica (Roxb.), Dioscorea alata L., Ipomoea batatas (leaves and tuber) L., Mannihot esculentum Crantz, Momordica charantia L., Phaseolus vulgaris L., Pouzolzia bennettiana Wight, Diplazium esculentum (Retz.) Sw., Centella asiatica L., Houttuynia cordata Thunb. (green salad), Gynura crepedioides (BTH.) Moore (green salad), Spilanthus oleraceae Murr., Litsea cubeba (Lour) Pers. (spice), Clerodendron viscosum Vent., Solanum indicum L. (green salad), Solanum torvum Sw. (Green salad), Solanum etiopicum, Allium sativum Linn., and Allium hooleri L. (green salad). These plant species are generally sold in the local market at reasonable price. The tender shoots of selected bamboo species like Dendrocalamus hamiltonii Hook. f. collected in bulk was prepared by cutting it into strips or pieces and boiled. The boiled shoots are chopped finely and packed in jars, bamboo tubes (Chunga) or even in plastic buckets and was kept for 5-10 days for fermentation. After fermentation, the taste of chopped shoots becomes sour. Fresh bamboo shoots and its fermented products were sold in the local market as edible foodstuffs. Important domestic uses concerned presently cultivated species of Livistona jenkensiana Griff. used for thatching and Bambusa tulda Roxb. and B. pallida Munro., for house building work. Traditional dyeing of clothes and food items were derived from plant species namely Illicium griffithii Hook. and Rubia cordifolia L. These plant species are currently cultivated in the gardens to meet regular use due to their less accessibility. Some of the plant parts used as a food source was also ingested as a remedy: Clerodendron colebrookianum (blood pressure), Momordica charantia (diabetes mellitus), Lindera neesiana, Solanum etiopicum, and Solanum indicum (intestinal parasitic worms like round and tape worms

\section{Religious or ritual plants}

The Monpa community in the eastern Himalayan province of Arunachal Pradesh follow Mahayana sect of Buddhism and are famous for hand-made paper for writing religious scripts in Monasteries (locally called "Gonpa") from stem bark of Daphne papyracea (Thymelaeaceae) Wall. Flowering twigs of Thysanolaena maxima has traditionally been used for broom making and to support the cotton wick to offer daily butter lighting in monastery. However, under the influence of modern society, today D. papyracea was not being used for making paper for writing Buddhist scripts as revealed during field survey work. Gymnocladus assamicus ripe pods are soaked in water and used to rubbed palms when preparing torma, a kind of sweet made of rice flour offered to the Lord Buddha during various festival ceremonies at Monasteries. The Monpa houses are built of stones and timber decorated with a small altars and chapels with statues of Lord Buddha. Offering water in little seven cups and burning butter lamps and herbal incense sticks with few herbal leaves (Pinus wallichiana A.B. Jackson, Pinus longifolia Roxb. and Thuja occidentalis L.) (Cupressaceae) are daily rituals. These plant species are cultivated within the premises of monasteries for their use during religious festival called Choskar. It was of common belief that burning of such herbal leaf create clean and refreshing atmosphere inside the Gonpa. The heart wood of pine tree was used for lighting of the street at night and ignition of firewood at home in olden days where there was no supply of electricity and kerosene. The resins extracted from pine wood are used as adhesives. Bulbs of Allium sativum and Allium hookeri are used in rituals and to protect against the evil spirit. A leaf of banana has long been used during festival ceremony in monastery to offer foodstuffs to local 
participants. The rhizomes of Zingiber officinale and Mannihot esculentum remains an integral component of daily rituals among the Monpas religious life.

\section{Local beverage (local beer) plants}

The traditional consumption of a variety of alcoholic beverages since time immemorial is still an integral part of different ethnic communities in the north-eastern region of India. Popular traditional beer, locally known as "bhangchang", was prepared from rice (Oryza sativa L.), finger millet (Eleusine coracana Geartn.), maize (Zea mays L.) and buckwheat (Fagopyrum esculentum Moench). "Bhangchang" has traditionally been used and served in all festive occasions, birth and marriage ceremonies. A diverse knowledge system exists among the Monpa women to prepare the nutritionally rich foods and fermented beverages, which play an important role in their day to day socio-cultural and spiritual occasions. A Monpa woman uses some of the wild plants as antimicrobial and they believed that these plants are responsible for the healthy growth of yeast during the process of fermentations. During the field study, we have documented the use of young leaves and twigs of certain species like Piper betle, Solanum indicum, Buddleja asiatica and Hedyotis scandens as common growth supplements during the preparation of fermentation starter cultures containing brewer's yeast (locally called phamzas). The most frequently cited species were Buddleja asiatica and Hedyotis scandens. They believed that consumption of rice beer is good for health and act as a remedy for various ailments may be attributed to medicinal properties of the herbs used in the preparation of starter cultures.

\section{Ethno-veterinary plants}

A few plants were used to improve the health state and growth of livestocks. The leaves of Cannabis sativa was given to the cattle and goat to cure dysentery and diarrhoea (These diseases were identified by the presence of watery stool and blood). The stem of wild Musa paradisica L., was regularly given to cattle particularly during pregnancy to enhance the yield of milk. A paste powder obtained from the whole plant of Plantago major and Ageratum conyzoides are commonly tied to the affected portions of cattle and goat to relieve from severe pain and inflammations. Gymnocladus assamicus ripe pods are soaked in water and used as disinfectant for cleaning wounds and parasites like leeches and lice on the skin of livestocks. The fully ripe pods soaked in water are used as soap for bathing because it does not cause harm to soft skin and burning sensation to eyes. Leaves are used as green manure in agricultural field crops. Gymnocladus assamicus is a critically rare and endangered plant species and also endemic to the north-eastern region of India [29].

\section{Ichthyotoxic and fish feed plants}

Community seasonal fishing and hunting are of great economic activities of many tribal people including Monpa ethnic group in addition to agriculture. The study revealed a wealth of indigenous knowledge and procedures related to poison fishing with the aid of poisonous plants. This easy and simple method of fishing are forbidden in urban areas but still practiced in remote tribal areas. The active ingredients were released by macerating the appropriated plant parts with the help of wooden stick or hammer, which were then introduced into the water environment. Depending upon time and conditions, the fish begin to float to the surface where they can easily be collected with bare hand. A total of seven plant species, namely Castanopsis indica, Derris scandens, Aesculus assamica, Polygonum hydropiper, Spilanthes acmella, Ageratum conyzoides, and Cyclosorus extensus were used to poison fish during the month of June-July every year and leaves of three species like Ipomoea batatas, Mannihot esculenta, and Zea mays were used as common fish foodstuffs. The two main molecular groups of fish poisons in plants (the rotenones and the saponins) as well as a third group of plants which liberate cyanide in the water account for nearly all varieties of fish poisons [63]. The underground tuber of Aconitum ferrox was widely used in arrow poisoning to kill ferocious animals like bear, wild pigs, gaur and deer. The killing of Himalayan bear was very common practice among the tribal people and the gall bladders are highly priced in the local market. The dried gall bladders of bear are given orally in low doses to cure malaria since ancestral times.

\section{Conclusions}

This ethno-botanical survey results probably revealed the rich wealth of indigenous knowledge and usage custom of traditional plants associated with rural people of Arunachal Pradesh. Despite their use in traditional medicines, plant species documented in the present field work have been extensively used for improving the health of livestock, fish foodstuffs, ethno-fishing technology, local fermentation technologies, religious and food plants as well. There was no written document of traditional healing knowledge and transmission to the future generation take place only through oral communication. The immediate and serious threat to the local medical practice in the study area seems to have come from the increasing influence of modernization, deforestation due to anthropogenic activities and migration of the younger generations to urban areas leaving a gap in the cultural beliefs and practices of indigenous society. However, there was a potential threat to the medicinal flora of the area as a result of the increasing trend of shifting cultivation (annual clearing of forest) and cultural changes signaling the need for serious efforts to create public awareness so that the appropriate measures are taken to conserve the suitable environments 
required to protect the medicinal plants in the natural ecosystems. More detailed ethnopharmacological investigations need to be conducted in this area particularly in regard to conservation strategies and sustainable use of medicinal plants.

\section{Acknowledgements}

We are grateful to study participants and traditional healers of Monpa ethnic group for sharing their valuable indigenous knowledge on botanical plants during the ethno-pharmacological field survey work.

\section{Author details \\ 'Department of Molecular Biology and Biotechnology, Tezpur University, Assam 784 028, India. ${ }^{2}$ Department of Microbiology and Cell Biology, Indian Institute of Science, Bangalore 560 012, India. ${ }^{3}$ Department of Botany, Rajiv Gandhi University, Rono Hills, Doimukh, Arunachal Pradesh 791112, India. ${ }^{4}$ Division of Pharmacognosy, Department of Pharmaceutical Technology, Jadavpur University Kolkata 700 032, India.}

\section{Authors' contributions}

NDN developed and designed the research study and conducted field survey work data and wrote the manuscript. ST helped in preliminary identification of plant species and corrected the manuscript. MM and SCM read, supervised and approved the final manuscript. All authors have read and approved the final manuscript.

\section{Competing interests}

The authors declare that they have no competing interests.

Received: 21 September 2010 Accepted: 14 October 2011 Published: 14 October 2011

\section{References}

1. WHO: General Guidelines for Methodologies on Research and Evaluation of Traditional Medicine. Geneva, Switzerland; 2001.

2. Sinha RK: Ethnobotany-The Renaissance of Traditional Herbal Medicine. InaShree Publishers, Jaipur, India; 1996, 242.

3. Dubey NK, Kumar R, Tripati P: Global promotion of herbal medicine: India'sopportunity. Curr. Science 2004, 86:37-41.

4. Pal SK, Shukla Y: Herbal medicine: current status and the future. Asian Pacific Jour of Cancer Prevention 2003, 4:281-288.

5. State Population Census Report: Department of Economics and Statistics, West Kameng District, Bomdila, Government of Arunachal Pradesh Publication. 2001.

6. Haridasan K, Anupam S, Bhuyan LR, Bisht NS: Medicinal Plants sector in Aruncahal Pradesh: an overview. Indian Forster 2003, 129:37-47.

7. Deb S, Arunachalam A, Das AK: Indigenous knowledge of Nyishi tribes on traditional agroforestry systems. Indian Jour Trad Knowledge 2009, 8:41-46.

8. Sarmah A, Haridasan K, Bisht NS: Development of medicinal plants as aan economic venture in Arunachal Pradesh: Prospects and constraints. Arunachal Forster News 2000, 18:85-92.

9. Murtem G: Common vegetable of Nyishi tribe of Arunachal Pradesh. Arunachal for News 2000, 18:64-66.

10. Anonymous: Medicinal Plants of Arunachal Pradesh. State Forest Research Institute Bulletin Itanagar, Arunachal Pradesh; 2001, 12.

11. Tag H, Das AK: Ethnobotanical notes on Hill Miri Tribe of Arunachal Pradesh. Indian Jour Trad Knowledge 2004, 3:80-85.

12. Doley B, Gajurel PR, Rethy P, Singh B, Buragohain R, Potsangbam S: Lesser known Ethno medicinal Plants Used by the Nyishi community of Papum Pare District, Arunachal Pradesh. Jour Biol Sci Res 2010, 1:34-36.

13. Goswami P, Soki D, Jaishi A, Das M, Sarma HN: Traditional healthcare practices among the Tagin tribe of Arunachal Pradesh. Indian Jour Trad Knowledge 2009, 8:127-130

14. Srivastava RC, Singh RK, Mukheriee TK: Indigenous biodiversity of Apatani plateau: Learning on biocultural knowledge of Apatani tribe of Arunachal Pradesh for sustainable livelihoods. Indian Jour Trad Knowledge 2010, 9:432-442.
15. Kagyung R, Gajurel PR, Rethy P, Singh B: Ethnomedicinal plants used for gastro-intestinal diseases by Adi tribes of Dehang-Debang Biosphere Reserve in Arunachal Pradesh. Indian Jour Trad Knowledge 2010, 9:496-501.

16. Sen P, Dollo M, Choudhury MD, Choudhury D: Documentation of traditional herbal knowledge of Khamptis of Arunachal Pradesh. Indian Jour Trad Knowledge 2009, 7:438-442.

17. Sarmah R, Adhikari D, Mazumder M, Arunachalam A: Traditional medicobotany of Chakma community residing in the northwestern periphery of Namdapha national Park in Arunachal Pradesh. Indian Jour Trad Knowledge 2008, 7:587-593.

18. Dutta R, Bhattacharjya KB: An indigenous community fishing practice of Tirap district, Arunachal Pradesh. Indian Jour Trad Knowledge 2008, 7:624-626.

19. Kala CP: Ethnomedicinal botany of Apatani in the Eastern Himalayan region of India. J Ethnobiol Ethnomedicine 2005, 1:11

20. Rawat MS, Chaudhury S: Ethnobotany of Arunachal Pradesh (Nyishi and Apatani tribes). Bishen Singh and Mahendra Pal Singh Publication, Dehradun, India; 1998

21. Namsa ND, Hui T, Mandal M, Das AK, Kalita P: An ethnobotanical study of traditional anti-inflammatory plants used by the Lohit community of Arunachal Pradesh, India. Jour Ethnopharmacol 2009, 125:234-245.

22. Namsa ND, Mandal M, Tangjang S: Anti-malarial herbal remedies of northeast India, Assam: An ethnobotanical survey. Jour Ethnopharmacol 2011, 133:565-572.

23. Choudhery HJ: Materials for the Flora of Arunachal Pradesh Botanical Survey of India, Kolkata; 1996.

24. Hooker JD: In Flora of British India. Volume 6. Ashford, Kent, England: L. Reeve and Co. Ltd., NR; 1894

25. Haridasan K, Rao RR: In Forest Flora of Meghalaya. Volume H-II. Bishen Singh Mahendra Pal Singh, Dehradun; 1987

26. Trotter R, Logan M: Informant consensus: a new approach for identifying potentially effective medicinal plants. In Plants in indigenous medicine and diet: biobehavioural approaches. Volume 91. Edited by: Etkin NL. Bedfort hills, New York: Redgrave Publishers; 1986:112.

27. Heinrich M: Ethnobotany and its role in drug development. Phytother Res 2000, 14:479-488.

28. Cook FEM: Economic Botany Data Collection Standard; Prendergast, Royal Botanic Gardens, Kew. 1995.

29. Ayyanar M, Ignacimuthu S: Traditional knowledge of Kani tribals in Kouthalai of Tirunelveli hills, Tamil Nadu, India. Jour Ethnopharmacol 2005, 102:246-255.

30. Ragupathy S, Steven GNewmaster, Murugesan M, Balasubramaniam V, UIHuda MMuneer: Consensus of the 'Malasars' traditional aboriginal knowledge of medicinal plants in the Velliangiri holy hills, India. Jour Ethnobiol Ethnomed 2008, 4:8.

31. Bhattarai S, Chaudhary RP, Cassandra LQ, Robin SLT: The use of medicina plants in the trans-himalayan arid zone of Mustang district, Nepal. Jour Ethnobiol Ethnomed 2010, 6:14.

32. Giday M, Teklehaymanot $\mathrm{T}$, Animut $\mathrm{A}$, Mekonnen $\mathrm{Y}$ : Medicinal plants of the Shinasha, Agew-Awiand Amhara peoples in northwest Ethiopia. Jour Ethnopharmacol 2007, 110:516-525.

33. Owuor BO, Kisangau DP: Kenyan medicinal plants used as antivenin: a comparison of plant usage. J Ethnobiol Ethnomedicine 2006, 2:7.

34. Teklehaymanot T, Giday M: Ethnobotanical study of medicinal plants used by people in Zegie Peninsula, Northwestern Ethiopia. J Ethnobiol Ethnomedicine 2007, 3:12.

35. Yineger $\mathrm{H}$, Kelbessa $\mathrm{E}$, Bekele $\mathrm{T}$, Lulekal E: Ethnoveterinary medicinal plants at Bale Mountains National Park, Ethiopia. Jour Ethnopharmacol 2007, 112:55-70.

36. Muthu C, Ayyanar M, Raja N, Ignacimuthu S: Medicinal plants used by traditional healers in Kancheepuram District of Tamil Nadu, India. Jour Ethnobiol Ethnomedicine 2006, 2:43.

37. Uniyal SK, Singh KN, Jamwal P, L B: Traditional use of medicinal plants among the tribal communities Chhota, Western Himalaya. Jour Ethnobiol Ethnomedicine 2006, 2:14

38. Shafi PM, Nambiar MKG, Clery RA, Sarma YR, Veena SS: Composition and antifungal activity of the oil of Artemisia nilagirica (Clarke) pamp. Jour Essential Oil Res 2004, 16:377-379.

39. Prarthana T, Poulami B, Souryadeep M, Tapas KH, Amarendra P, Prasanta KB: Antibacterial, antisecretory and antihemorrhagic activity of Azadirachta 
indica used to treat cholera and diarrhea in India. Jour Ethnopharmacol 2007, 111:607-612.

40. Wilson EA, Demmig-Adams B: Antioxidant, anti-inflammatory, and antimicrobial properties of garlic and onions. Nutrition and Food Science 2007, 37:178-183.

41. Nath SC, Bordoloi DN: Clerodendron colebrookianum, a folk remedy for the treatment of hypertension in north eastern India. Int Jour Pharmacol 1991, 29:127-129.

42. Devi Rajlakshmi, Sharma DK: Hypolipidemic effect of different extracts of Clerodendron colebrookianum Walp in normal and high-fat diet fed rats. Jour Ethnopharmacol 2004, 90:63-68.

43. Yang H, Wang J, Hou AJ, Guo YP, Lin ZW, Sun HD: New steroids from Clerodendrum colebrookianum. Fitoterapia 2000, 71:641-648.

44. Choudhury BI, Khan ML, Arunachalam A, Arunachalam K: Gymnocladus assamicus Kanjilal ex P.C. Kanjilal fruit - A soap substitute. Natl Prod Radiance 2007, 6:427-429.

45. Menon S, Baharul I, Choudhury MLK, Peterson A. Townsend: Ecological niche modeling and local knowledge predict new populations of Gymnocladus assamicus a critically endangered tree species. Endang Species Res 2010, 11:175-181.

46. Comai S, Dall'Acqua S, Grillo A, Castagliuolo I, Gurung K, Innocenti G: Essential oil of Lindera neesiana fruit: Chemical analysis and its potential use in topical applications. Fitoterapia 2010, 81:11-16.

47. Shetty S, Udupa S, Udupa L, Somayaji N: Wound healing activity of Ocimum sanctum Linn with supportive role of antioxidant enzymes. Indian Jour Physiol Pharmacol 2006, 50:163-8.

48. Ojewole JAO, Emmanuel OAWE, Witness DHC: Antidiarrhoeal activity of Psidium guajava Linn. (Myrtaceae) leaf aqueous extract in rodents. Jour Smooth Muscle Res 2008, 44:195-207.

49. Rahim N, Donald JG, Haruo W, Sabita RR, Chariya C, Endtz Hubert Ph, Alam Munirul: Antibacterial Activity of Psidium guajava Leaf and Bark against Multidrug-Resistant Vibrio cholerae: Implication for Cholera Control. Japan Jour Infect Dis 2010, 63:271-274.

50. Gutiérrez RMP, Mitchell S, Solis RV: Psidium guajava: a review of its traditional uses, photochemistry and pharmacology. Jour Ethnopharmacol 2008, 117:1-17.

51. Fassil H: "We do what we know": Local Health Knowledge and Homebased Medicinal Plant Use in Ethiopia. PhD Thesis Green College, Oxford University; 2003.

52. Gedif $\mathrm{T}$, Hahn H: The use of medicinal plants in self-care in rural central Ethiopia. Jour Ethnopharmacol 2003, 87:155-161.

53. Leung L, Birtwhistle R, Kotecha JHS, Cuthbertson S: Anti-diabetic and hypoglycaemic effects of Momordica charantia (bitter melon): a mini review. The British Jour Nutrition 2009, 102:1703-1708.

54. Liu CH, Yen MH, Tsang SF, Gan KH, Hsu HY: Antioxidant triterpenoids from the stems of Momordica charantia. Food Chemistry 2010, 118:751-756.

55. Swaroop A, Prakash GA, Kumar SA: Simultaneous determination of quercetin, rutin and coumaric acid in flowers of Rhododendron arboreum by HPTLC. Chromatographia 2005, 62:649-652.

56. Upadhyay PB, Roy S, Kumar A: Traditional uses of medicinal plants among the rural communities of Churu district in the Thar Desert, India. Jour Ethnopharmacol 2007, 113:387-399.

57. Panghal M, Vedpriya A, Sanjay Y, Sunil K, Jaya PY: Indigenous knowledge of medicinal plants used by Saperas community of Khetawas, Jhajjar District, Haryana, India. Jour Ethnobiol Ethnomed 2010, 6:4.

58. Teklehaymanot T: Ethnobotanical study of knowledge and medicinal plants use by the people in Deklsland in Ethiopia. Jour Ethnopharmacol 2009, 124:69-78.

59. Giday M, Asfaw Z, Elmqvist T, Woldu Z: An ethnobotanical study of medicinal plants used by the Zay people in Ethiopia. Jour Ethnopharmacol 2003, 85:43-52.

60. Collins S, Martins X, Mitchell A, Teshome A, Arnason JT: Quantitative ethno-botany of two East Timorese cultures. Economic Bot 2006, 60:347-361.

61. Deribe K, Amberbir A, Getachew B, Mussema Y: A historical overview of traditional medicine practices and policy in Ethiopia. Ethiopian Jour Health Development 2006, 20:127-134.

62. Ignacimuthu S, Ayyanar M, Sivaraman K: Ethnobotanical investigations among Tribes in Madurai District of Tamil Nadu (India). Jour Ethnobiol Ethnomed 2006, 2:25.
63. Bearez P: First Archaeological Indication of Fishing by Poison in a Sea Environment by the Engoroy Population at Salango (Manabí, Ecuador). Jour of Archaeological Science 1998, 25:943-948.

64. Rao MR, Reddy IB, Ramana T: Antimicrobial activity of some Indian medicinal plants. Indian J Microbiol 2006, 46:259-262.

65. Shafi PM, Nambiar MKG, Clery RA, Sarma YR, Veena SS: Composition and antifungal activity of the oil of Artemisia nilagirica (Clarke) Pamp. J Essen Oil Res 2004, 16:377-379.

66. Singh SP, Shukla HS, Singh RS, Tripathi SC: Antifungal properties of essential oil of Ageratum conyzoides L. Science Lett 1986, 9:97.

67. Abena AA, Ouamba JM, Keita A: Anti-inflammatory, analgesic and antipyretic activities of essential oil of Ageratum conyzoides. Phyto Res 1996, 10:164-165.

68. Moura ACA, Silva ELF, Fraga MCA, Wanderley AG, Afiatpour P, Maia MBS: Anti-inflammatory and chronic toxicity study of the leaves of Ageratum conyzoides L. in rats. Phytomed 2005, 12:38-142.

69. Murthy KS, Rao DN, Rao DK, Murthy LBS: A preliminary study on hypoglycemic and anti-hyperglycemic effects of Azadirachta indica. Indian J Pharmacol 1978, 10:247-250.

70. Koley KM, Lal J, Tandan SK: Anti-inflammatory activity of Azadirachta indica (neem) leaves. Fitoterapia 1994, 65:524-528.

71. Jayanthi MK, Dhar M: Anti-inflammatory effects of Allium sativum (garlic) in experimental rats. Biomolecules 2011, 31:84-89.

72. Chang SL, Chiang YM, Chang CL, Yeh HH, Shyur LF, Kuo YH, Wu TK, Yang WC: Flavonoids, centaurein and centaureidin, from Bidens pilosa, stimulate IFN- $\gamma$ expression. J Ethnopharmacol 2007, 112:232-236.

73. Jin SG, Chuen LC, Koo MWL: Inhibitory effects of Centalla asiatica water extract and asiaticoside on inducible nitric oxide synthase during gastric ulcer healing in rats. Plant Medica 2004, 70:1150-1154.

74. Jung HJ, Nam JH, Lee KT, Lee YS, Choi J, Kim WB, Won YC, Park HJ: Structure-activity relationships of polyhydroxyursane-type triterpenoids on the cytoprotective and anti-inflammatory effects. Natl Prod Sci 2007, 13:33-39.

75. Harsha VH, Hebbar SS, Hegde GR, Shripati V: Ethnomedical knowledge of plants used by Kunabi tribe of Karnataka, India. Fitoterapia 2002, 73:281-287.

76. Rajurkar BM: Morphological study and medicinal importance of Clerodendrum infortunatum Gaertn. (Verbenaceae), found in Tadoba National park, India. J Pharmaceut Res Health Care 2010, 2:216-220.

77. Patil KS, Warke PD, Chaturvedi SC: Hypoglycemic properties of Ficus glomerata fruits in alloxan-induced diabetic rats. I Natl Remedies 2006, 6:120-123.

78. Mangathayaru K, Lakshmikant J, Sundar NS, Swapna RGXF, Vasantha J: Antimicrobial activity of Leucas aspera flowers. Fitoterapia 2005, 76:752-754.

79. Meghashri S, Kumar HV, Gopal S: Antioxidant properties of a novel flavonoid from leaves of Leucas aspera. Food Chem 2010, 122:105-110.

80. Yang Y, Jiang J, Qimei L, Yan X, Zhao J, Yuan H, Qin Z, Wang M: The fungicidal terpenoids and essential oil from Litsea cubeba in Tibet. Molecules 2010, 15:7075-7082.

81. Comai S, Dall Acqua S, Grillo A, Castagliuolo I, Gurung K, Innocenti G: Essential oil of Lindera neesiana fruit: Chemical analysis and its potential use in topical applications. Fitoterapia 2010, 81:11-16.

82. Kolawole OT, Abiona FE, Kolawole SO, Ayankunle AA, Olaniran I: Effect of Momordica charantia fruit extract on normal and alloxan-diabetic rats. Internatl J Pharmacol 2011, 7:532-535.

83. Shetty S, Udupa S, Udupa L: Evaluation of antioxidant and wound healing effects of alcoholic and aqueous extract of Ocimum sanctum Linn in rats. Evidence-based Compl Alter Med 2008, 5:95-101.

84. Abinash PS, Venkat KR, Pragya S, Pranab G, Utpal B: Ethnobotany of medicinal plants used by Assamese people for various skin ailments and cosmetics. J Ethnopharmacol 2006, 106:149-157.

85. Birdi T, Poonam D, Brijesh S, Pundarikakshudu T, Arvind N, Noshir A: Newer insights into the mechanism of action of Psidium guajava L. leaves in infectious diarrhoea. BMC Compl Alter Med 2010, 10:33.

86. Venkatrao N, Koroth SMd, Satyanarayana S, Hemamalini K, Shanta Kumar SM: Antidiarrhoeal and anti-inflammatory activity of fruit rind extracts of Punica granatum. Indian Drugs 2007, 44:909-914.

87. Gomez-Flores R, Calderon CL, Scheibel LW, Tamez-Guerra P, RodriguezPadilla C, Tamez-Guerra R, Weber RJ: Immunoenhancing properties of Plantago major leaf extract. Phyto Res 2000, 14:617-622. 
88. Verma N, Singh AP, Amresh G, Sahu PK, Rao CV: Protective effect of ethyl acetate fraction of Rhododendron arboreum flowers against carbon tetrachloride-induced hepatotoxicity in experimental models. Indian J Pharmacol 2011, 43:291-295.

89. Syu WJ, Don MJ, Lee GH, Sun CM: Cytotoxic and novel compounds from Solanum indicum. J Natl Prod 2001, 64:1232-1233.

90. Kamaraj C, Rahuman Abdul, Elango Gandhi, Bagavan Asokan, Abdul Abduz Zahir: Anthelmintic activity of botanical extracts against sheep gastrointestinal nematodes, Haemonchus contortus. Parasitol Res 2010, Abdul.

91. Joaquim MDA, Alexis VN, Adyary FL, Franco ML, Maria G: Antioxidant activity of phenolics compounds from sugar cane (Saccharum officinarum L.) juice. Plant Foods for Human Nutrition 2006, 61:187-192.

92. Akoachere JFTK, Ndip RN, Chenwi EB, Ndip LM, Njock TE, Anong DN: Antibacterial effect of Zingiber officinale and Garcinia kola on respiratory tract pathogens. East African Med J 2002, 79:588-592.

doi:10.1186/1746-4269-7-31

Cite this article as: Namsa et al:: Ethnobotany of the Monpa ethnic group at Arunachal Pradesh, India. Journal of Ethnobiology and Ethnomedicine 2011 7:31.

\section{Submit your next manuscript to BioMed Central} and take full advantage of:

- Convenient online submission

- Thorough peer review

- No space constraints or color figure charges

- Immediate publication on acceptance

- Inclusion in PubMed, CAS, Scopus and Google Scholar

- Research which is freely available for redistribution

Submit your manuscript at www.biomedcentral.com/submit 